\title{
On Some Japanese Tetranychid Mites of Economic Importance ${ }^{1}$
}

\author{
By Shôzô EHARA \\ Zoological Institute, Faculty of Science, Hokkaido University, Sapporo
}

The purpose of the present paper is to record taxonomic notes of several Japanese spider mites, with description of a new species. The material on which this study is based was recently forwarded to the author by many economic entomologists for identification; each species is more or less injurious to agricultural crops. The following is a list of the mites concerned in this paper.

1. Eotetranychus smithi PRITCHARD et BAKER

2. Paratetranychus ilicis (McGREGOR)

3. Tetranychus desertorum BANKs

4. Tetranychus phaselus n. sp.

5. Tetranychus kanzawai KISHIDA

The author is indebted to Prof. Tohru Uchida for his invaluable suggestions, to Dr. Edward W. BAKER for the loan of type materials, and to Dr. A. Earl PrITchard for informing diagnostic characters of a mite. Moreover, the author wishes to thank many workers who have generously contributed specimens for this study.

Eotetranychus smithi Pritchard et Baker (Figs. 1 15)

Eotetranychus smithi PRITCHARD and BAKER, 1955, p. 192, Figs. $149 \sim 150$.

Female.-Body from above oval, 310 to $410 \mu$ long and $260 \mu$ wide, red in colour. Rostrum reaching the distal portion of femur I. Terminal sensillum of palpus less than one and one half times as long as wide; dorsal sensillum spindleshaped. Mandibular plate (ratio of breadth to length, 7.0:10) rounded in front. Relative lengths of segments in leg I as follows: trochanter, 12; femur, 25 30; genu, 14; tibia, 15; tarsus (empodium exclusive), 25. Tarsus I dorsally provided with two adjacent sets of duplex setae on the middle; with five tactile and one sensory setae proximal to proximal set of duplex setae, and with two tactile setae ventrad of the duplexes; proximal duplex setae of tarsus I with the distal member three and one half times as long as the proximal member; distal duplex setae of the tarsus with the distal member about six times as long as the proximal member. Tibia I with nine tactile and one sensory setae. Tarsus II with three tactile and one sensory setae proximal to duplex setae which are more or less in line with other three tactile setae; tibia II with eight tactile setae; tibia III with six tactile setae. Empodia with a mediodorsal spur. Peritreme hooked distally, the hooked part broader than the rest. The integumentary striae are transverse between the inner lumbar setae while longitudinal between the inner sacral setae; the area between these setae striated transversely. Dorsal setae not arising from tubercles, slender, tapering, pubescent, and much longer than intervals between their neighbouring bases; inner sacral setae $88 \mu$, outer sacral setae $64 \mu$, clunal setae $37 \mu$, and postanal setae $28 \mu$. Genital flap with transverse striae; area immediately anterior to the flap with longitudinal striae.

Male.-Body measuring $270 \mu$ long and $170 \mu$ wide. Terminal sensillum of palpus about two and one half times as long as wide, bluntly pointed distally; dorsal sensillum spindle-shaped. Tarsus I with four tactile (five tactile in one specimen) and three sensory setae proximal to proximal set of duplex setae, and with two tactile

1 Contribution No. 483 from the Zoological Institute, Faculty of Science, Hokkaido University, Sapporo.

(Received for publication, September 2, 1960) 


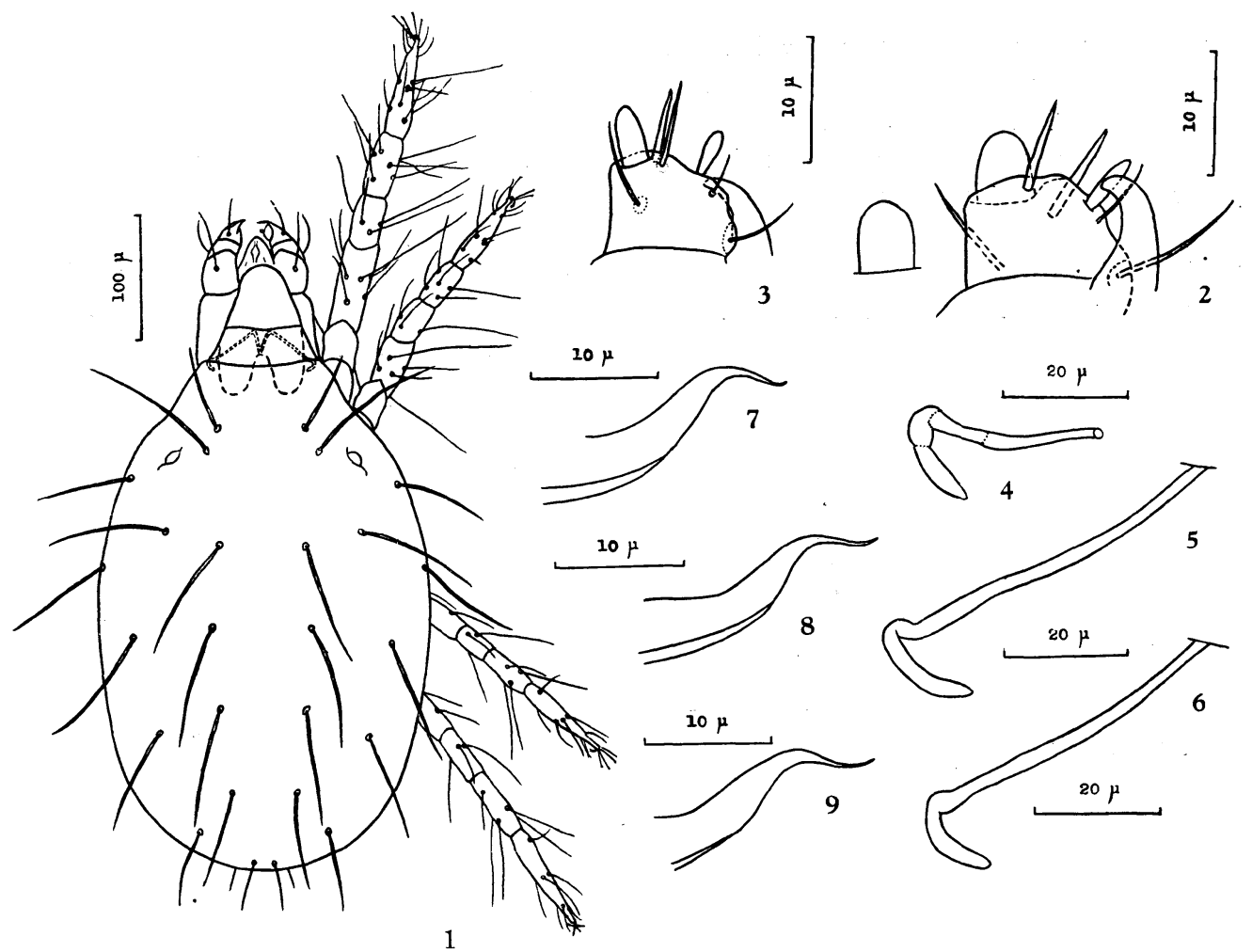

Figs. 1 9. Eotetranychus smithi. 1, dorsal view of female. 2, distal segment of palpus of female. 3 , distal segment of palpus of male. 4, lateral view of peritreme of female. 5,6 , dorsal view of peritreme of female. $7,8,9$, aedeagus.
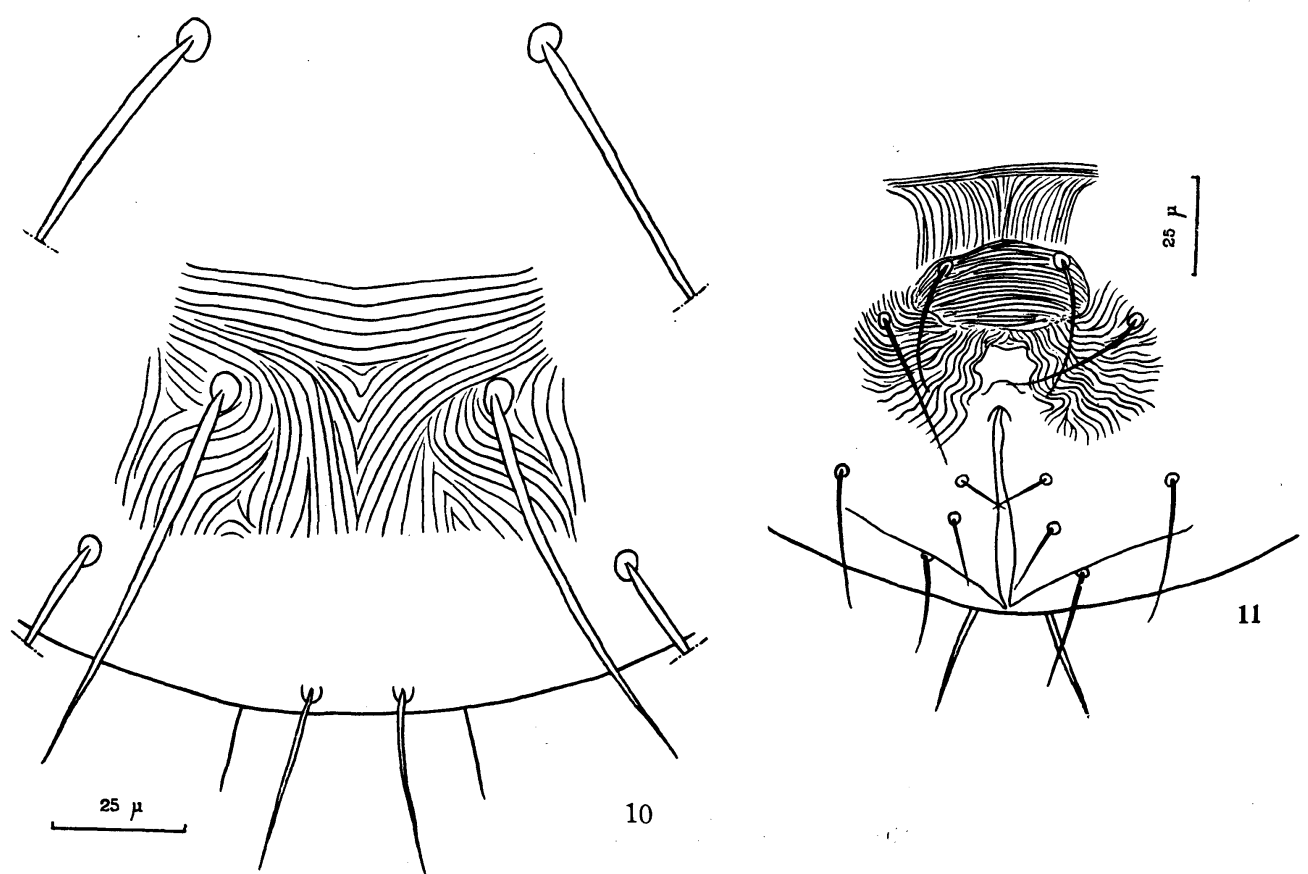

Figs. 10 11. Eotetranychus smithi. 10, dorsal view of caudal part of female opisthosoma, showing striae. 11, ventral view of caudal part of female opisthosoma, showing striae and setae. 
setae ventrally located at the level of the duplexes; tibia I with nine tactile and four sensory setae. Tarsus II with three tactile and setae, and with one tactile seta close to the duplex setae and two tactile setae ventrad of the duplex; tibia II with eight tactile setae; tibia III with six tactile setae.

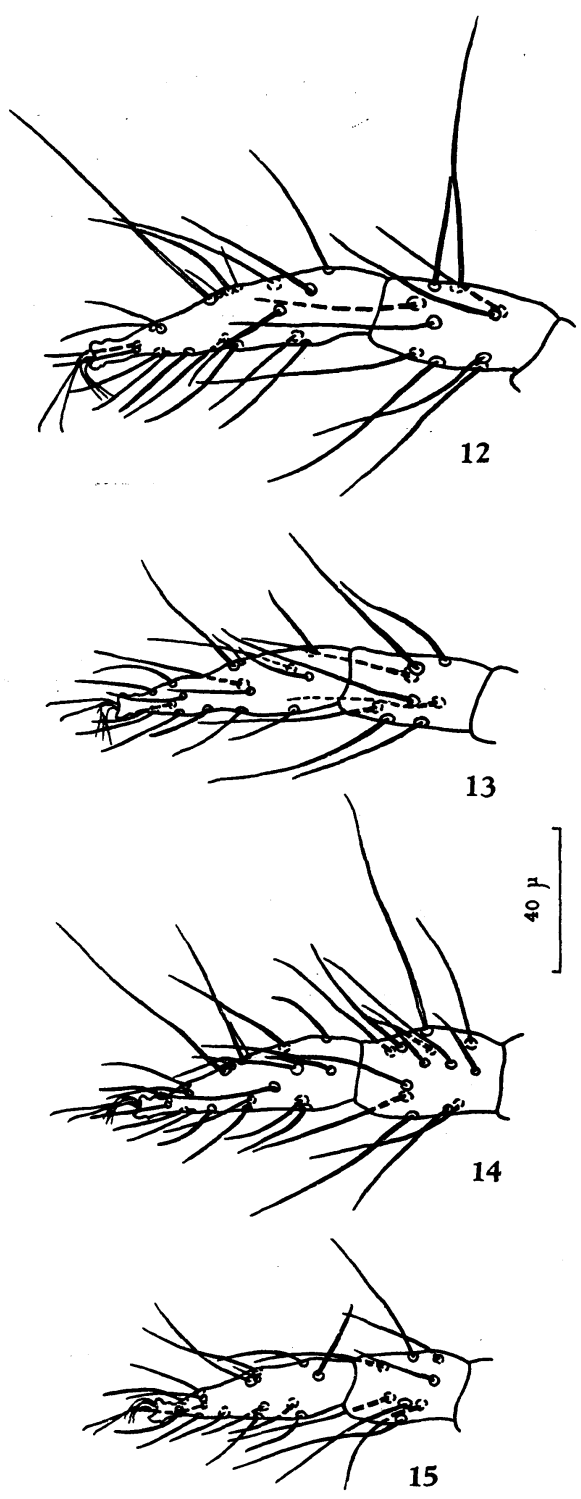

Figs. 12 15. Eotetranychus smithi. 12, tarsus and tibia I of female. 13, tarsus and tibia II of female. 14, tarsus and tibia I of male. 15 , tarsus and tibia II of male.
Middle pair of digits of empodium I stouter than other two pairs which are very slender. Aedeagus bent dorsad to form a sigmoid, caudally directed, distal part which is tapering apically.

Specimens examined.-Kyushu: Yukuhashi, Fukuoka Pref., 6 송ㅅㅇ \& 25 우우, 6-X-1956, 4송ㅅㅇ \& 14 우우, 13-X-1956, on grape, M. Miyahara leg. Types of this species have also been examined.

Hosts and distribution.-Japan (Kyushu), first recorded; U. S. A. Parasitic on grape (new host record), rambler rose and Rubus phoenicolasius.

Remarks. - The Japanese specimens have been compared with the types. It has been revealed that the former generally accords with the latter. This species is unique in the red body colour among Japanese representatives of this genus. According to a personal letter from $\mathrm{Mr}$. M. Mryahara the mite is a considerably serious pest of grapes in northern Kyushu.

Paratetranychus ilicis '(MCGREGOR)

(Figs. 16 27)

Tetranychus ilicis McGREGOR, 1917, p. 586, P1.106, Figs. $1 \sim 7$.

Paratetranychus ilicis, McGREGor, 1919, p. 673, Fig. 10, P1. 79, Fig. 17; McGREGOR, 1950, p. 340, P1. 38, Fig. 14.

Oligonychus ilicis, Pritchard and Baker, 1955, p. 305, Figs. $257 \sim 259$.

Female.-Body from above oval, $360 \mu$ long and $250 \mu$ wide, reddish brown in colour. Rostrum approximately reaching the middle of femur I. Terminal sensillum of palpus about one and one half times as long as wide; dorsal sensillum very slender. Mandibular plate (ratio of breadth to length, 7.1: 10) slightly notched mediodistally. Relative lengths of segments in leg I as follows: trochanter, 12; femur, 29; genu, 13; tibia, 15; tarsus (empodial claw exclusive), 23. Tarsus I dorsally furnished with two adjacent sets of duplex setae; with three tactile and one sensory setae proximad of proximal set of duplex setae, and with one tactile seta ventrad of the duplexes; proximal duplex setae of tarsus I with the proximal member about one 


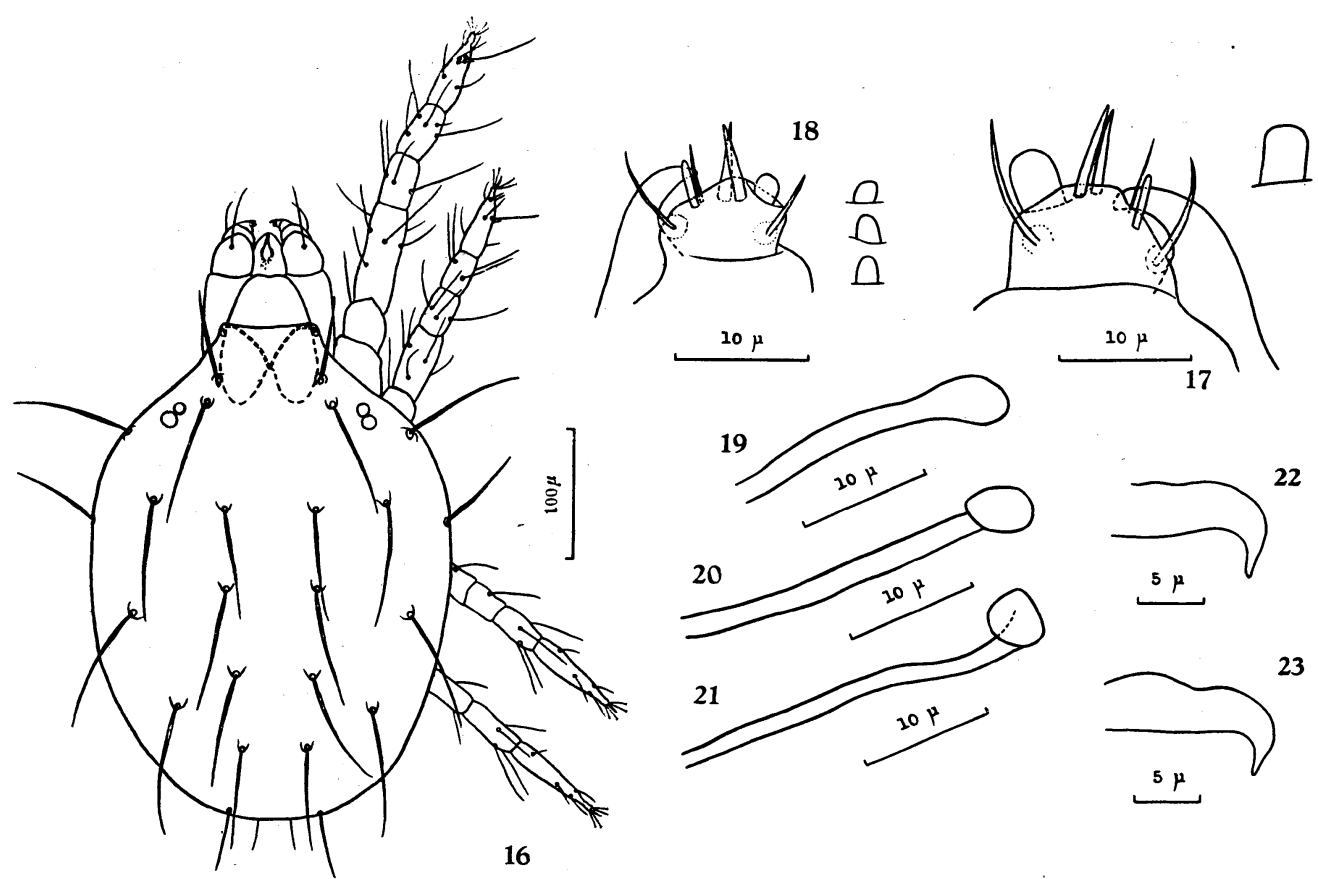

Figs. 16 23. Paratetranychus ilicis. 16, dorsal view of female. 17, distal segment of palpus of female. 18, distal segment of palpus of male. 19, 20, lateral view of peritreme of female. 21 , dorsal view of peritreme of female. 22,23 , aedeagus.

third as long as the distal member; distal duplex setae of the tarsus with the proximal member about one sixth as long as the distal member. Tibia I with seven tactile and one sensory setae. Tarsus II with two tactile and one sensory setae proximal to duplex setae, and with one tactile seta near the duplex setae and another tactile seta ventrad of the duplex; tibiae II and III each with five tactile setae. Empodial claw I with four pairs of proximoventral setae. Peritreme narrow, dilated at the distal end. Dorsal setae set on small tubercles which are often not evident in mounted specimens, pubescent, slender, and much longer than distances between their bases; outer sacral setae much shorter than inner sacral setae. Genital flap with transverse striae; area immediately anterior to the flap with longitudinal striae.

Male.-Body $280 \mu$ long and $190 \mu$ wide. Terminal sensillum of palpus about as long as wide, shorter than dorsal sensillum which is very slender. Tarsus I with three tactile and three sensory setae proximad of proximal set of duplex setae, and with one tactile seta ventrad of the duplexes; tibia I with seven tactile and four sensory setae. Tarsus II with two tactile and one sensory setae proximal to duplex setae, and with one tactile seta close to the duplex setae and another tactile seta ventrad of the duplex; tibiae II and III each with five tactile setae. Empodial claw I with three pairs of proximoventral setae. Outer and inner sacral setae shorter than other dorsal setae, the outer sacrals being the shortest. Aedeagus bent downward to form the distal portion which attenuates to a tip rather abruptly.

Specimens examined.-Honshu: Shinshiro, Aichi Pref., 2우우, 15-IV-1959 (on tea), M. OsaKabe leg., 3송송 \& 18우 우 ${ }^{1}, 29-$ IV-1959 (on tea), 4余客,-11-V-1959 (on tea), Y. ÔTA leg.; Kyushu: Tanushimaru, Fukuoka Pref.,

\footnotetext{
${ }^{1}$ Collected together with specimens of Tetranychus kanzawai KisHida.
} 
2송소 \& 15우우, 24-VII-1956 (on azalea), I. TAteishi leg.; Kurume, Fukuoka Pref., 4소옹 \& 2 우우, 15-VI-1957 (on azalea), 2송 \& 26 우 우, 8-X-1957 (on azalea), 4 우 우 ${ }^{1}, 7$ XII-1957 (on azalea), K. INOUE leg.

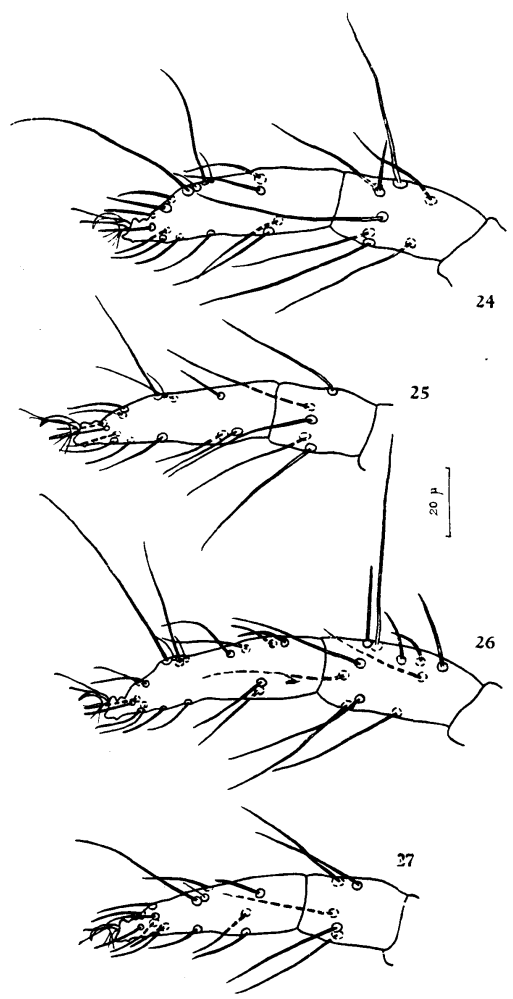

Figs. 24 27. Paratetranychus ilicis. 24, tarsus and tibia I of female. 25, tarsus and tibia II of female. 26, tarsus and tibia I of male. 27 , tarsus and tibia II of male.

Hosts and distribution.-Japan (Honshu, first recorded; Kyushu); U.S. A. Parasitic on tea (new host record), azalea, laurel, camellia, holly and boxwood.

Remarks.-Paratetranychus ilicis was recorded from Japan (Kyushu) by PRITCHARD and BAKeR (1955). Recently, InOUe (1959) studied its biology and control in Kyushu. In U. S. A. this mite is well known as a pest of camellias and azaleas.

\section{Tetranychus desertorum BANKS}

Tetranychus desertorum, Ehara, 1956a, p. 144, Figs. $22 \sim 26$.

It is known that $T$. desertorum is a pest of egg-plant, cucumber and melon in Okayama Prefecture (Ehara, 1956a). The females are purple red in colour. Specimens from central Japan have been available in the present study: 3 우 우, 27-VI-1960, 4송ㅅㅇ \& 10 우우, 4-VII-1960, T. IsHikawa leg., bred in vinyl house at Ôji, Tokyo (laboratorial, host Phaseolus vulgaris Linnaeus' ${ }^{2}$ ); original locality, Ôji; original host,soybean ${ }^{2}$; collector, $T$. IsHIKAWA.

Tetranychus phaselus n. sp.

(Figs. 28 39)

Female.-Body from above oval, 380 to $530 \mu$ long and 260 to $350 \mu$ wide, yellowish red in colour. Rostrum reaching the distal portion of femur I. Terminal sensillum of palpus approximately twice as long as wide, dorsal sensillum spindle-shaped, much shorter than the former. Mandibular plate (ratio of breadth to length, 6.1:10) nearly rounded in front or only slightly incised. Relative lengths of segments in leg I: trochanter, 15; femur, 35; genu, 19; tibia, 20; tarsus (empodium exclusive), 32 . Tarsus I dorsally with two separated sets of duplex setae on the middle; with four tactile setae proximad of proximal set of duplex setae, and with one sensory seta located at the level of the proximal duplex; proximal duplex setae of tarsus I with the proximal member about one fifth as long as the distal member; distal duplex setae of the tarsus with the proximal member about one seventh as long as the distal member.- Tibia I with nine tactile and one sensory setae. Tarsus II with three tactile and one sensory setae proximal to duplex setae, and with one tactile seta close to the duplex setae and two tactile setae ventrad of the duplex setae; tibia II with seven tactile setae; tibia III

1 Collected together with specimens of Brevipalpus obovatus Donnadieu (=Brevipalpus inornatus . (BANKS), according to PRITCHARD and BAKER, 1958).

2 New host records. 

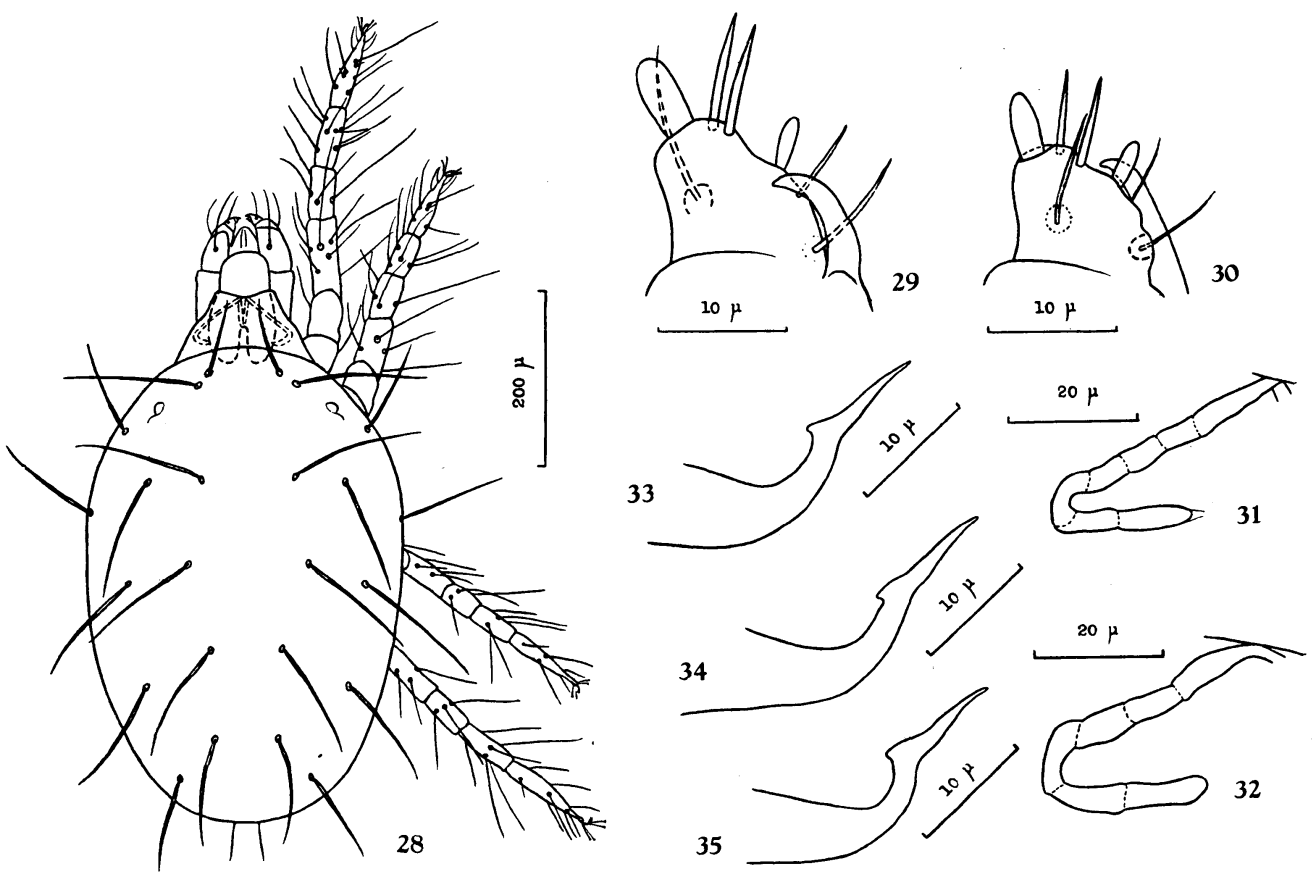

Figs. 28 35. Tetranychus phaselus n. sp. 28, dorsal view of female. 29, distal segment of palpus of female. 30 , distal segment of palpus of male. 31,32 , peritreme of female, dorsal view. $33,34,35$, aedeagus.
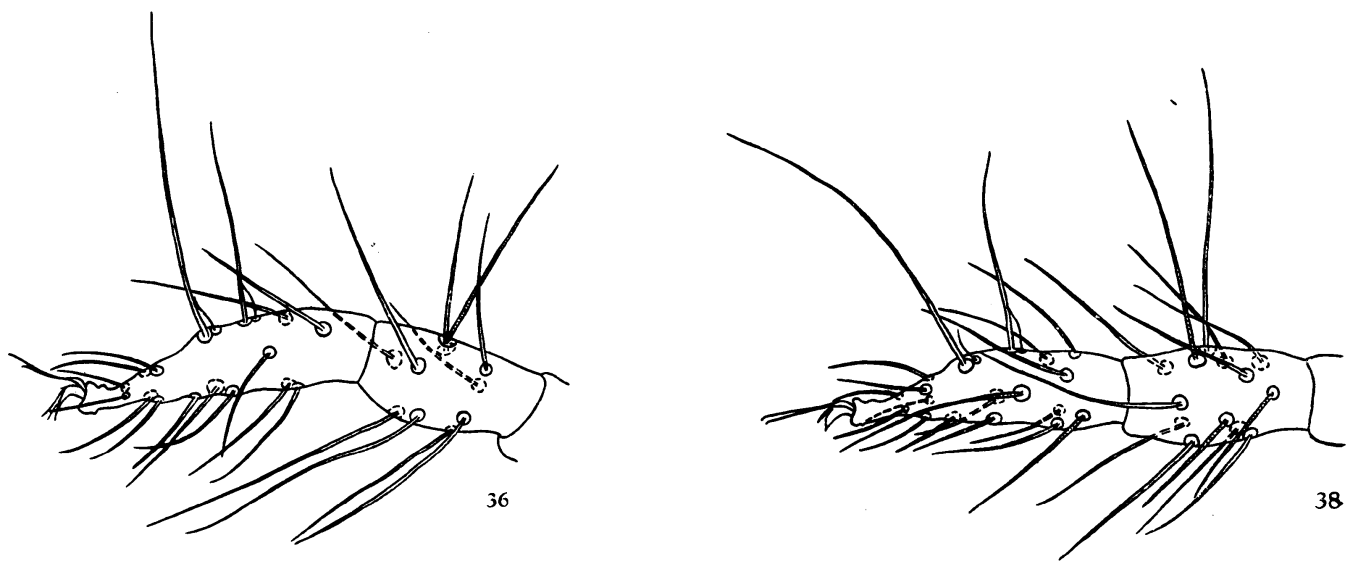

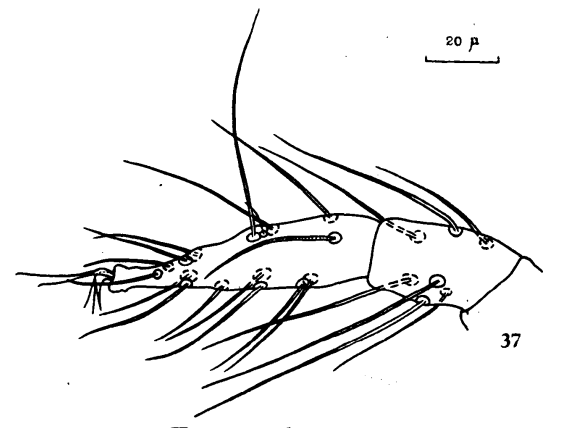

Figs. 36 37. Tetranychus phaselus n. sp. 36, tarsus and tibia I of female. 37, tarsus and tibia II of female.

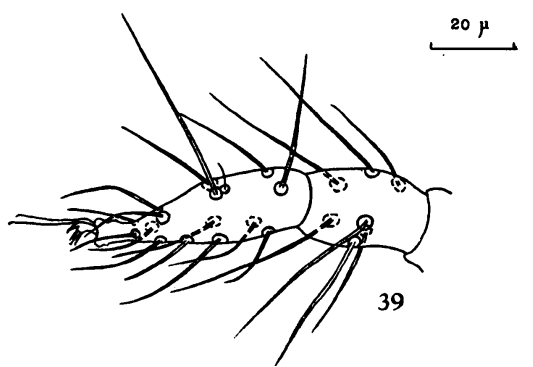

Figs. 38〜39. Tetranychus phaselus n. sp. 38, tarsus and tibia I of male. 39 , tarsus and tibia II of male. 
with six tactile setae. Empodia consisting of normal three pairs of digits, empodium I with a tiny mediodorsal spur. Peritreme U-shaped in distal part. Dorsum of body with longitudinal striae between the inner lumbar setae and between the inner sacral setae, the area between these setae striated transversely. Dorsal integumentary folds bearing small lobes, triangularly rounded to semicircular, showing rather the type of Tetranychus cinnabarinus (BorsDuval). Dorsal setae not set on tubercles, slender, tapering, pubescent, and much longer than intervals between bases. Genital flap with transverse striae; area immediately anterior to the flap striated longitudinally.

Male.-Body measuring $300 \mu$ long and $190 \mu$ wide. Terminal sensillum of palpus slender, dorsal sensillum shorter than the former. Tarsus I with four tactile and two sensory setae proximal to proximal set of duplex setae, and with one sensory seta present at the level of the proximal duplex; tibia I with nine tactile and four sensory setae. Tarsus II with three tactile and one sensory setae proximad of duplex setae, and with one tactile seta close to the duplex and two tactile setae ventrad of the duplex; tibia II with seven tactile setae; tibia III with six tactile setae. Empodia with a distinct mediodorsal spur which is larger in legs I and II. The aedeagus as in Figs. 33 35: the axis of the terminal knob forming a definite angle with the axis of the shaft, with a sharp anterior angulation and with an exceedingly longer, slender angulation. The latter angulation is dorsocaudally directed and tapers to a tip.

Holotype. ${ }^{1-}$ -, , 1-II-1960 (Y. UEBAyASHI \& H. Yoneda), bred in green house at Ôiso, Kanagawa Pref.(laboratorial host,Phaseolus vulgaris Linnaeus); original locality, Ninomiya, Kanagawa Pref.; original host, Pha- seolus vulgaris LinNaEus; collector, Y. UEBAYASHI \& H. YONEDA.

Raratypes. ${ }^{1-13}$ 우 우, 20-I-1960, 7个㑒 \& 38우우, 1-II-1960, other data same as in the holotype.

Distribution.-Japan (Honshu).

Remarks.-The aedeagus of Tetranychus phaselus $\mathrm{n}$. sp. shows that this species is allied to T. marianae MCGREGoR ${ }^{2}, 1950$, which is known to occur in Saipan, the Tinian Islands, U. S. A., Puerto Rico, Nicaragua and Argentina, but the terminal knob of the aedeagus of this new species is extremely long and very slender. Further, the new species is different from $T$. marianae in the male empodia with the distinct mediodorsal spur.

\section{Tetranychus kanzawai KISHIDA}

Tetranychus kanzawai, EHARA, 1956 b,p. 504, Figs. $15 \sim 25$.

This species was recently redescribed, with notes on synonymy, host plants and distribution (EHARA, 1956 b). Since then further many collections of this mite have been available to the author. As is listed below, this mite is known to show a wide range in host selection; furthermore, it is proved that the mite occurs predominantly on tea plants in Japan. This mite is new to the fauna of Shikoku and Kyushu.

Specimens examined ${ }^{3}$.- Honshu: Tokyo, 4 今㑒, 4-VIII-1958 (on poplar ${ }^{4}$ ), K. Hatano leg.; Musashi, Saitama Pref., 2송ㅅㅇ \& 12 우 우, 15-VI-1957 (on tea), M. InUzukA leg.; Kanaya, Shizuoka Pref., 2송ㅅㅇ \& 11 우우, 24-VI-1957 (on tea), M. Osakabe leg.; Takamori, Nagano Pref., 4송ㅅㅇ \& 8우우, 30VIII-1957 (on pear), T. Miyashita leg.; Shinshiro, Aichi Pref., 2송소 \& 2 우 우,29-IV-1959 (on tea), Y. ÔTA leg.; Kameyama, Mié Pref., 4송송 \& 20우우, 28-V-1957 (on tea), S. Yокочама leg.; Tenri, Nara Pref., $3 \hat{\delta} \hat{\jmath}$ $\& 13$ 우 우, 1-VI-1957 (on tea), M. IMANISHI leg.; Uzi, Kyoto Pref., 3송ㅇㅇ \& 26 우우, 15-

1 The types are preserved in the Zoological Institute.

2 Types of $T$. marianae have been here examined.

3 The collections from teas were all offered by Mr. M. OsAKABE of the Tea Division, National Tôkai-Kinki Agricultural Experiment Station, Kanaya.

4 Preliminarily recorded in EHARA, 1959. 
V-1957(on tea), H. W'ATANABE leg;; Shikoku: Kôchi, Kôchi Pref., 3송ㅅㅇ \& 19 우 우, 21- V-1957 (on tea),N.Sakamoto leg.; Kyushu: Chikugo, Fukuoka Pref., 4송ㅅㅇ \& 12 우우, 13-IX-1957 (on tea), H. Yamamura leg.; Ureshino, Saga Pref., 4송송 \& 9우우, 22-V-1957 (on tea), K. Yoshida leg.; Ômachi, Saga Pref.; 3今实 \& 11 우우, 10-VI-1957 (on citrus'), M. SEKI leg.; Ogi, Saga Pref., 2ㅅㅇㅅㅅㅇ \& 9 우 우, 3-X-1957 (on Boehmeria nivea $\mathrm{GAUD}^{1}{ }^{1}$ ), 1 소 \& 24 우 우, 26-VI-1957 (on Commelina communis LiNNAEUS $^{1}$ ), M. SeKr leg.; Kawaminami, Miyazaki Pref., 2송송 \& 16 우우, 18-V-1957 (on tea), S. Mryama leg.; Chiran, Kagoshima Pref., 4송송 \& 24우우, 20-V-1957 (on tea), K. Okamura leg.; Kagoshima, Kagoshima Pref., 2송소 \& 5 우 우, 22-VI-1956 (on hydrangea $^{1}$ ), 5송송 \& 4 우 우, 22-VI-1956 (on clover ${ }^{1}$ ), 3송ㅅㅇ \& 8우우, 27-VI-1956(on dahlia ${ }^{1}$ ), 3个ㅇㅇㅅ \& 7 우우, 22-VI-1956 (on peach), S. MAEDA leg.

\section{REFERENCES}

EhaRA, S. (1956a) Japan. J. Appl. Zool. 21: 139 147.

Ehara, S. (1956b) J. Fac. Sci. Hokkaido Univ. Ser. 6, Zool. 12: 499 510.

EHARA, S. (1959) Hoppô-Ryngyô 11: 90〜94. (In Japanese.)

Inoue, K. (1959) Proc. Assoc. P1. Prot. Kyushu 5: 67 69. (In Japanese.)

McGregor, E. A. (1917) Proc.. U. S. Nat. Mus. 51: 581 590, Pls. 101 107.

McGREGOR, E. A. (1919) Proc. U. S. Nat. Mus. 56: $641 \sim 679$, Pls. $76 \sim 81$.

MCGREGOR, E. A. (1950) Amer. Midl. Nat. 44: $257 \sim 420$.

Pritchard, A. E. \& E. W. Baker (1955) Mem. Pac. Coast Ent. Soc. 2: 1 472, 1 Pl.

Pritchard, A. E. \& E. W. Baker (1958) Univ. Calif. Publ. Ent. 14: 175 274.

\section{摘要 \\ 農業上有害なハダニ類数種について}

江 原 昭 三

北海道大学理学部動物学教室

1) Eotetranychus smithi PRITCHARD et BAKER

スミスハダニ（新和名）

福岡県においてブドウ（新寄主植物）に寄生し, 日本 新記録種である。赤色であることは日本産の本属の種類 の中で特異である。

2) Paratetranychus ilicis (McGREGOR)

チビコブハダ二（新和名）

愛知県のチャ, 福岡県のツッジに寄生していた標本を 研究した。本州からは初めての記録であり, 一方チャは 新寄主植物である。特徴は背毛が小さいこぶからはえて いることで, 和名注この点に基づく。

3) Tetranychus desertorum BANks

アシノワハダニ（新和名）

東京王子産の標本を研究した。日本では彷来, 岡山県 からのみ知られていた。雌（脱皮直後を除く）はいくぶ ん紫がかった赤色である。和名は雌の第 1 脚のふ(跗)節 の基部近くに 6 本の毛がほぼ同一線上に生じ脚の輪のよ
うに見える点に基づき命名した。

4) Tetranychus phaselus EHARA, n. sp. (新種) サガミハダニ（新和名）

日本曹達株式会社生物研究所（神奈川県大磯町）で飼 育していた 標本を 模式標本としてここに 新種を 記載し た。原産地は神奈川県二宮町で原寄主植物, 飼育中の寄 主植物ともインゲンである。赤色種で, 雌第 1 脚のじょ く(裖) 盤は背部に小突起を持つ。雄の交尾器はかま(鎌) 状に長く延びている。和名は相模の意味である。

5) Tetranychus kanzawai KISHIDA

$$
\text { カンザワハダニ }
$$

四国と九州を新産地として記録した。多くの寄主植物 のなかでチャは重要である。すなわち日本の主要チャ産 地 (埼玉, 静岡, 愛知, 三重, 奈良, 京都, 高知, 福岡, 佐賀, 宮崎, 鹿児島の諸府県) で本種がチャに寄生する ことを知りえた。また佐賀県ではミカン（新寄主植物） を害する。他に若干の新寄主植物を記録した。

1 New host records. 